\title{
Mosquitoes collected on Pohnpei Island, Mokil Atoll and Pingelap Atoll, Pohnpei State, the Federated States of Micronesia (Diptera: Culicidae)
}

\author{
Shinichi NodA ${ }^{*, 1)}$, Sota Yamamoto ${ }^{1)}$ and Takako Toma ${ }^{2)}$ \\ * Corresponding author: Kagoshima University Research Center for the Pacific Islands, \\ 1-21-24, Korimoto, Kagoshima 890-8580, Japan (E-mail: snoda@cpi.kagoshima-u.ac.jp) \\ ${ }^{1)}$ Kagoshima University Research Center for the Pacific Islands, 1-21-24, Korimoto, Kagoshima 890-8580, Japan \\ 2) Laboratory of Medical Zoology, School of Health Sciences, Faculty of Medicine, University of the Ryukyus, \\ 207 Uehara, Nishihara, Okinawa 903-0215, Japan
}

(Received: March 15 2013; Accepted: August 26 2013)

\begin{abstract}
Mosquito larval surveys were carried out on Pohnpei Island, Mokil Atoll and Pingelap Atoll, Pohnpei State, the Federated States of Micronesia in November 2007 and August 2010. On Pohnpei Island, a total of 1,161 larval mosquitoes belonging to six species were collected at 59 various natural and artificial habitats. They were identified as Aedes albopictus, Ae. hakansoni, Ae. oakleyi, Culex quiquefasciatus, Cx. maplei and Cx. annulirostris. Aedes albopictus was only collected in two habitats, a small plastic container and a tire. It may be notable that $A e$. albopictus and Ae. oakleyi were newly reported in Pohnpei State. Aedes hakansoni was the predominant species. On Mokil Atoll, a total of 682 larval mosquitoes belonging to three species were collected at 49 habitats. They were identified as Ae. albopictus, Ae. marshallensis and Cx. quiquefasciatus. Aedes albopictus was collected in 20 habitats (40.8\%) that were of small or medium size. Aedes marshallensis was also collected from small- and mediumsized habitats. On Pingelap Atoll, a total of 870 larval mosquitoes belonging to four species were collected from 46 habitats. They were identified as Ae. aegypti, Ae. marshallensis, Ae. vexans noctunus and Cx. quiquefasciatus. Among them, Ae. aegypti was the predominant species which was collected in 21 (45.7\%) small to large habitats. Aedes marshallensis was also collected from a wide range of habitat sizes. Mokil Atoll and Pingelap Atoll are highly dengue-sensitive, because Ae. albopictus and Ae. aegypti were widely distributed on them. Efforts should be taken to reduce potential breeding sites for Aedes mosquitoes in these areas.
\end{abstract}

Key words: Aedes aegypti, Aedes albopictus, Pohnpei, Mokil, Pingelap, Federated States of Micronesia

\section{INTRODUCTION}

The Federated States of Micronesia (FSM) includes four states, Kosrae, Pohnpei, Chuuk and Yap. Yap is the westernmost state. A dengue fever outbreak was reported from these islands in June and July 1995 (Savage et al., 1998). Entomological investigations implicated a native mosquito species, Aedes hensilli, as a vector of the dengue virus (Savage et al., 1998; Noda et al., 2005). The dengue fever outbreak that occurred in Yap from May 2004 to January 2005 started right after a natural disaster, Typhoon Sudal (Martin, 2005). Six cases were exported to Japan via a group of visiting school children, without any known secondary spread (Martin, 2005; Nukui et al., 2006). Dengue fever cases have occurred in Yap every year since 2007 (WHO, 2010). There is a strong possibility that an outbreak of dengue fever will occur in the other three states of the FSM. However, little information is available regarding vector mosquito species. To determine the geographical distributions of vector mosquitoes, entomological surveys were carried out in the FSM. This report describes mosquito fauna and breeding sites of mosquitoes on Pohnpei Island, Mokil Atoll and Pingelap Atoll, Pohnpei State, the FSM.

\section{Materials And Methods}

Surveys of larval mosquitoes on Pohnpei Island, Mokil Atoll and Pingelap Atoll were carried out in November 2007 and August 2010 (Fig. 1). Pohnpei Island is high, volcanic and roughly circular, its coast is lined with coves and jutting peninsulas and it is covered with a thick jungle. The interior contains rugged mountain ridges and deep valleys. It has an average diameter of $21 \mathrm{~km}$ and a land area of $334 \mathrm{~km}^{2}$. Pohnpei Island is the largest island in the FSM. The highest peak is Ngihneni at $791 \mathrm{~m}$. The coastline is mainly composed of tidal flats and mangrove swamps. The town of Kolonia has an average annual rainfall of $4,877 \mathrm{~mm}$ and Pohnpei's interior often receives a whopping $10,000 \mathrm{~mm}$ of rain, making it one of the rainiest places on Earth. The average annual temperature is $27^{\circ} \mathrm{C}$ and north-easterly trade winds persist during most of the year (Galbraith et al., 2000). The population of Pohnpei State is 34,900 (estimation in 2007), and $90 \%$ of the population livies on Pohnpei Island. 


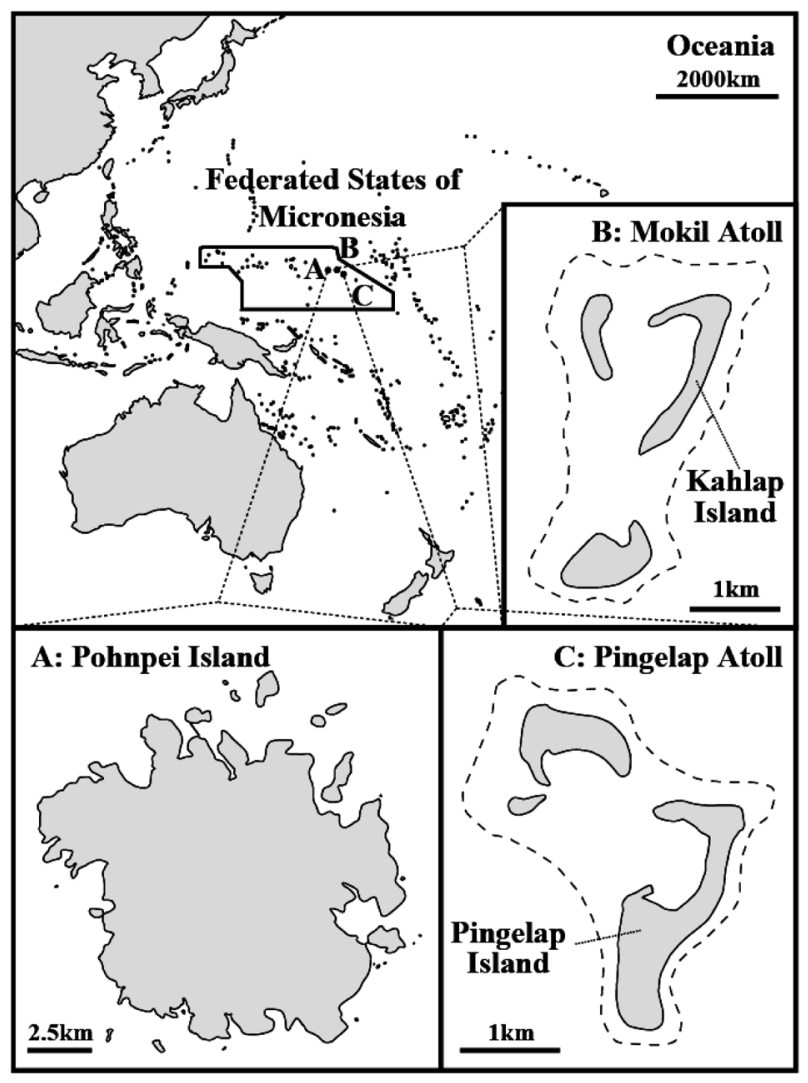

Fig. 1. Maps of Pohnpei Island (A), Kahlap Island of Mokil Atoll (B) and Pingelap Island of Pingelap Atoll (C), Pohnpei State, the Federated States of Micronesia.

Pohnpei State includes eight outlying atolls, each covering an area of less than $2.6 \mathrm{~km}^{2}$. To the southeast, almost like stepping stones down to Kosrae, are Mokil Atoll and Pingelap Atoll, which are located 129 and $225 \mathrm{~km}$ from Pohnpei Island. Mokil Atoll's three islets total approximately $1.3 \mathrm{~km}^{2}$ of land. About 100 people live on Kahlap Island, the largest and only inhabited islet. A $300 \mathrm{~m}$ airstrip is serviced by Caroline Islands Air. Pingelap Atoll also has three islets. About 300 people live on Pingelap Island. Like Mokil, Pingelap has a $300 \mathrm{~m}$ airstrip that is serviced by Caroline Islands Air.

Larval collections were primarily carried out in sites near residence, and also on roadsides and in fields. When a habitat was small, all of the larvae were collected. When a habitat was large, fewer than 30 larvae were collected. When larvae were young and could not be identified to species, they were excluded from the number of individuals reported in the results. On Pohnpei Island, larvae were only collected from the northeast part in 2007, but they occurred throughout the island in 2010. Larvae were collected on Kahlap Island of Mokil Atoll and Pingelap Island of Pingelap Atoll. Larvae were collected from 14, 22 and 15 habitats in November 2007, and 45, 27 and 31 habitats in August 2010 on Pohnpei Island, Mokil Atoll and Pingelap Atoll, respectively. The sampled habitats were composed of coconut shells, stumps of banana, cans, plastic containers, ceramic cups, bottles, tree holes, rock pits, coconut casings, metallic containers, tires, discarded refrigerator, concrete frame, plastic water barrels, metallic drums, concrete water tanks, wells, water pools and taro (Cyrtosperma merkusii) patches. Larvae were sampled using a pipette and dipper. All of the larvae collected in 2007 were preserved in $70 \%$ ethanol, but some of the larvae that were collected in 2010 were reared to the adult stage. Larvae and adults were identified to species using the keys and descriptions of Bohart (1957) and Bohart and Ingram (1946). The first survey period in November 2007 was very short and larvae were not reared to adults, making specific identification of Aedes larvae difficult. Therefore, we carried out subsequent larval survey on the three islands in August 2010. Some of the larvae collected in 2010 were reared to the adult stage, which permitted identification of the larvae collected in 2007 by comparison with individuals reared in 2010 .

\section{RESUlts}

A total of 2,713 larval mosquitoes belonging to nine species were collected at 154 various natural and artificial habitats on three islands in Pohnpei State (Tables 1-4). They were identified as Aedes (Stegomyia) aegypti, Ae. (Stg.) albopictus, Ae. (Stg.) marshanllensis, Ae. (Stg.) hakansoni, Ae. (Aedimorphus) vexans noctunus, Ae. (Adm.) oakleyi, Culex (Culex) quiquefasciatus, Cx. (Cux.) maplei and Cx. (Cux.) annulirostris.

A total of 1,161 larval mosquitoes belonging to six species were collected at 59 various natural and artificial habitats of Pohnpei Island (Table 1). They were identified as Ae. albopictus, Ae. hakansoni, Ae. oakleyi, $C x$. quiquefasciatus, $C x$. maplei and $C x$. annulirostris. Aedes albopictus was only collected from two habitats, a small plastic container and a tire. Aedes hakansoni was the predominant species being collected from $57.6 \%$ of habitats that were of small and medium size. Culex maplei was also collected from many habitats $(50.9 \%$ of habitats) that were of small to large size. The other three species were collected from relatively small numbers of habitats ( 1 to 7 habitats).

A total of 682 larval mosquitoes belonging to three species were collected from 49 habitats on Mokil Atoll (Table 2). They were identified as Ae. albopictus, Ae. marshallensis and Cx. quiquefasciatus. Aedes albopictus was collected in 20 habitats $(40.8 \%)$ that were of small and medium size. Aedes marshallensis was also collected at small- and medium-sized habitats. Culex quiquefasciatus was collected from large habitats.

A total of 870 larval mosquitoes belonging to four species were collected from 46 habitats on Pingelap Atoll (Table 3). They were identified as Ae. aegypti, Ae. marshallensis Ae. vexans noctunus and $C x$. quiquefasciatus. Among them, Ae. aegypti was the predominant species and was collected in 21 habitats (45.7\%) that were of small to large size. Aedes 
Table 1. Number of mosquitoes and habitat types from which they were collected on Pohnpei Island, Pohnpei State, the Federated States of Micronesia.

\begin{tabular}{|c|c|c|c|c|c|c|}
\hline \multirow{2}{*}{ Date of collected } & \multirow{2}{*}{ Species } & \multirow{2}{*}{$\begin{array}{c}\text { No. of } \\
\text { individuals }\end{array}$} & \multirow{2}{*}{$\begin{array}{c}\text { No. of } \\
\text { habitats }\end{array}$} & \multicolumn{3}{|c|}{ Habitat types } \\
\hline & & & & Small size* & Midium size ${ }^{* *}$ & Large size $\mathrm{e}^{* * *}$ \\
\hline \multirow[t]{6}{*}{ November 2007} & Aedes (Stegomyia) albopictus & 8 & 2 & Plastic container & Tire & \\
\hline & Aedes (Stegomyia) hakanssoni & 75 & 5 & Can & Tire, Plastic & \\
\hline & Aedes (Aedimorphus) oakleyi & 87 & 2 & & & Well, Water pool \\
\hline & Culex (Culex) quinquefasciatus & 19 & 1 & & Plastic container & \\
\hline & Culex (Culex) maplei & 205 & 5 & & $\begin{array}{l}\text { Plastic container, } \\
\text { Metallic container }\end{array}$ & \\
\hline & Total & 394 & 14 & & & \\
\hline \multirow[t]{6}{*}{ August 2010} & Aedes (Stegomyia) hakanssoni & 291 & 29 & $\begin{array}{l}\text { Coconut shell, } \\
\text { Can, Plastic } \\
\text { container, Rock } \\
\text { pit }\end{array}$ & $\begin{array}{l}\text { Plastic container, } \\
\text { Mettalic } \\
\text { container, Tire }\end{array}$ & \\
\hline & Aedes (Aedimorphus) oakleyi & 45 & 5 & & & $\begin{array}{l}\text { Metallic drum, } \\
\text { Concrete water } \\
\text { pool }\end{array}$ \\
\hline & Culex (Culex) quinquefasciatus & 99 & 5 & $\begin{array}{l}\text { Coconut shell, } \\
\text { Can }\end{array}$ & Plastic container & $\begin{array}{l}\text { Concrete water } \\
\text { pool }\end{array}$ \\
\hline & Culex (Culex) maplei & 329 & 20 & $\begin{array}{l}\text { Coconut shell, } \\
\text { Can, Coconut } \\
\text { casing, Rock pit }\end{array}$ & $\begin{array}{l}\text { Plastic container, } \\
\text { Metallic } \\
\text { container, Tire }\end{array}$ & $\begin{array}{l}\text { Concrete water } \\
\text { pool }\end{array}$ \\
\hline & Culex (Culex) annulirostris & 3 & 1 & Rock pit & & \\
\hline & Total & 767 & 45 & & & \\
\hline
\end{tabular}

* Size is less than $20 \mathrm{~cm}$.

** Saize is between $20 \mathrm{~cm}$ and $1 \mathrm{~m}$.

*** Saize is more than $1 \mathrm{~m}$.

Table 2. Number of mosquitoes and habitat types from which they were collected on Kahlap Island of Mokil Atoll, Pohnpei State, the Federated States of Micronesia.

\begin{tabular}{|c|c|c|c|c|c|c|}
\hline \multirow{2}{*}{ Date of collected } & \multirow{2}{*}{ Species } & \multirow{2}{*}{$\begin{array}{c}\text { No. of } \\
\text { individuals }\end{array}$} & \multirow{2}{*}{$\begin{array}{l}\text { No. of } \\
\text { habitats }\end{array}$} & \multicolumn{3}{|c|}{ Habitat types } \\
\hline & & & & Small size* & Midium size ${ }^{* *}$ & Large size $e^{* * *}$ \\
\hline \multirow[t]{4}{*}{ November 2007} & Aedes (Stegomyia) albopictus & 44 & 7 & $\begin{array}{l}\text { Coconut shell, } \\
\text { Can, Ceramic } \\
\text { cup, Bottle }\end{array}$ & & \\
\hline & Aedes (Stegomyia) marshallensis & 35 & 8 & $\begin{array}{l}\text { Coconut shell, } \\
\text { Ceramic }\end{array}$ & Plastic container & \\
\hline & Culex (Culex) quinquefasciatus & 257 & 8 & & & $\begin{array}{l}\text { Plastic container, } \\
\text { Metallic drum, } \\
\text { Concrete water } \\
\text { tank }\end{array}$ \\
\hline & Total & 336 & 22 & & & \\
\hline \multirow[t]{4}{*}{ August 2010} & Aedes (Stegomyia) albopictus & 122 & 13 & $\begin{array}{l}\text { Coconut shell, } \\
\text { Can, Ceramic } \\
\text { cup }\end{array}$ & $\begin{array}{l}\text { Plastic container, } \\
\quad \text { Metallic } \\
\text { container }\end{array}$ & \\
\hline & Aedes (Stegomyia) marshallensis & 137 & 14 & $\begin{array}{l}\text { Coconut shell, } \\
\text { Can, Ceramic } \\
\text { cup, Coconut } \\
\text { casing, Plastic } \\
\text { container }\end{array}$ & & \\
\hline & Culex (Culex) quinquefasciatus & 87 & 4 & & & $\begin{array}{l}\text { Plastic container, } \\
\text { Metallic } \\
\text { container, } \\
\text { Concrete water } \\
\text { tank }\end{array}$ \\
\hline & Total & 346 & 27 & & & \\
\hline
\end{tabular}

* Size is less than $20 \mathrm{~cm}$.

** Saize is between $20 \mathrm{~cm}$ and $1 \mathrm{~m}$.

*** Saize is more than $1 \mathrm{~m}$. 
Table 3. Number of mosquitoes and habitat types from which they were collected on Pingelap Island of Pingelap Atoll, Pohnpei State, the Federated States of Micronesia.

\begin{tabular}{|c|c|c|c|c|c|c|}
\hline \multirow{2}{*}{ Date of collected } & \multirow{2}{*}{ Species } & \multirow{2}{*}{$\begin{array}{c}\text { No. of } \\
\text { individuals }\end{array}$} & \multirow{2}{*}{$\begin{array}{c}\text { No. } \\
\text { of habitats }\end{array}$} & \multicolumn{3}{|c|}{ Habitat types } \\
\hline & & & & Small size* & Midium size ${ }^{* *}$ & Large size $e^{* * *}$ \\
\hline \multirow[t]{5}{*}{ November 2007} & Aedes (Stegomyia) aegypti & 140 & 8 & $\begin{array}{l}\text { Stump of } \\
\text { banana, Plastic } \\
\text { container }\end{array}$ & Metallic container & $\begin{array}{l}\text { Discarded } \\
\text { refrigerator, } \\
\text { Plastic water } \\
\text { barrel, Concrete } \\
\text { water tank }\end{array}$ \\
\hline & Aedes (Stegomyia) marshallensis & 32 & 3 & $\begin{array}{l}\text { Coconut shell, } \\
\text { Stump of } \\
\text { banana, Plastic } \\
\text { container }\end{array}$ & & \\
\hline & $\begin{array}{l}\text { Aedes (Aedimorphus) vexans } \\
\text { noctanus }\end{array}$ & 20 & 1 & & & Taro patch \\
\hline & Culex (Culex) quinquefasciatus & 81 & 5 & & Plastic container & $\begin{array}{l}\text { Plastic water } \\
\text { barrel, Concrete } \\
\text { water tank, } \\
\text { Well, Taro } \\
\text { patch }\end{array}$ \\
\hline & Total & 273 & 15 & & & \\
\hline \multirow[t]{4}{*}{ August 2010} & Aedes (Stegomyia) aegypti & 164 & 13 & $\begin{array}{l}\text { Stump of } \\
\text { banana, Plastic } \\
\text { container }\end{array}$ & $\begin{array}{l}\text { Plastic container, } \\
\quad \text { Metallic } \\
\text { container }\end{array}$ & $\begin{array}{l}\text { Metallic drum, } \\
\text { Concrete water } \\
\text { tank }\end{array}$ \\
\hline & Aedes (Stegomyia) marshallensis & 208 & 13 & $\begin{array}{l}\text { Coconut shell, } \\
\text { Stump of } \\
\text { banana, Plastic } \\
\text { container, Tree } \\
\text { hole }\end{array}$ & Plastic container, & Metallic drum \\
\hline & Culex (Culex) quinquefasciatus & 225 & 10 & & $\begin{array}{l}\text { Plastic container, } \\
\text { Metallic } \\
\text { container }\end{array}$ & $\begin{array}{l}\text { Metallic drum, } \\
\text { Concrete frame }\end{array}$ \\
\hline & Total & 597 & 31 & & & \\
\hline
\end{tabular}

* Size is less than $20 \mathrm{~cm}$.

** Saize is between $20 \mathrm{~cm}$ and $1 \mathrm{~m}$.

*** Saize is more than $1 \mathrm{~m}$.

Table 4. Distributions of mosquitoes on three islands of Pohnpei State, the Federated States of Micronesia.

\begin{tabular}{|c|c|c|c|}
\hline Species & Pohnpei Island & Kahlap Island of Mokil Atoll & Pingelap Island of Pingelap Atoll \\
\hline Aedes (Stegomyia) aegypti & & & $\bigcirc$ \\
\hline Aedes (Stegomyia) albopictus & $\bigcirc$ & $\bigcirc$ & \\
\hline Aedes (Stegomyia) marshallensis & & $\bigcirc$ & $\bigcirc$ \\
\hline Aedes (Stegomyia) hakanssoni & $\bigcirc$ & & \\
\hline Aedes (Aedimorphus) vexans noctanus & & & $\bigcirc$ \\
\hline Aedes (Aedimorphus) oakleyi & $\bigcirc$ & & \\
\hline Culex (Culex) quinquefasciatus & 0 & $\bigcirc$ & $\bigcirc$ \\
\hline Culex (Culex) maplei & $\bigcirc$ & & \\
\hline Culex (Culex) annulirostris & $\bigcirc$ & & \\
\hline
\end{tabular}

marshallensis was also collected from various sized habitats. Ae. vexans noctunus was only collected from taro patch. C. quiquefasciatus was collected from medium and large habitats.

\section{Discussion}

Ae. aegypti and Ae. albopictus are primary vectors of dengue virus in the Pacific (WHO, 2003), but various secondary vector species are also known (Guillaumot, 2005). This survey recorded six Aedes species on Pohnpei State. Ae. albopictus and Ae. oakleyi were recorded for the first time from Pohnpei State. However, Ae. senyavinensis and Ae. lameliferus were not collected, because this survey focused on residential areas. Knight and Hurbut (1949) reported that larvae of Ae. senyavinensis were numerous in clear water in the axils of young palms. Larvae of Ae. lameliferus occurred in mangrove swamps where they were found in water of palm axils and tree holes (Bohart and Ingram, 1946). Ae. aegypti was only collected on Pingelap Atoll 
during this survey, and it was the predominant species there. Aedes albopictus was collected on Pohnpei Island and Mokil Atoll. It was collected from two habitats on Pohnpei Island in 2007, but it was not collected in 2010. Aedes albopictus was widely distributed on Mokil Atoll. Aedes marshallensis was collected on Mokil Atoll and Pingelap Atoll, and it was widely distributed in both areas. In this survey, Ae. hesilli, which transmits the dengue virus in Yap State, was not collected on any of the three islands in Pohnpei State.

Kosrae State is the easternmost island of both the FSM and the Caroline Islands chain; it adjoins the Marshall Islands and Pohnpei State of the FSM. An outbreak of dengue fever on the Marshall Islands was confirmed in October 2011, and the government issued an emergency warning to prevent the spread of dengue fever (Ministry of Foreign Affairs, 2011). Unfortunately, the dengue virus was brought into Kosrae State in September 2012 after our entomological survey, and among 230 patients were confirmed positive between 26 September and 11 November. The infection rate was considerably high within the total population of Kosrae (Ministry of Foreign Affairs, 2012).

Dengue fever became a large health issue in all of the states of the FSM. Pohnpei Island is the main island of Phonpei State, and the capital of the FSM is located on the island. Many people visit Pohnpei Island from other islands for work, trading, shopping and other purposes. It is necessary to expedite measures to prevent the dengue virus from being carried into this area. Aedes albopictus, the main vector of dengue fever, was collected from a small plastic container and a tire on Pohnpei Island. These habitats were frequently found around houses on Pohnpei Island. Aedes hakansoni was the predominant species on Pohnpei Island. Females of Ae. hakansoni were not observed biting humans, either in nature or in the laboratory (Knight and Hurbut, 1949).

Mokil Atoll and Pingelap Atoll are highly denguesensitive, because Ae. albopictus and Ae. aegypti are widely distributed on them, respectively. These species also transmit other viruses. In 2007, Zika virus relatively mild disease characterized by rash, arthralgia and conjunctives on Yap Island, the FSM. This was the first time that Zika virus was detected outside of Africa and Asia (Duffy et al., 2009; Hayes, 2009). Aedes hensilli was the predominant mosquito species identified. Chikungunya virus is transmitted to human by virus-carrying Aedes mosquitoes. Chikungunya has been identified in nearly 40 countries of Africa and Asia. Therefore, efforts should be taken to reduce the potential for Aedes mosquitoes to breed in these areas. Environmental management should focus on the destruction, alternation, disposal or recycling of containers that produce larger numbers of adult Aedes mosquitoes. These programs should be conducted concurrently with health education programs and communications that encourage community participation in the planning, execution and evaluation of container-management programs (WHO, 2003).

\section{ACKNOWLEDGEMENTS}

We thank James Spensin, President of the College of Micronesia, who helped us conduct research in Pohnpei State, Federated States of Micronesia. We also thank the following people for arranging our survey in Pohnpei State: James Currie (Vice President for Cooperative Research and Extension) for the survey on Pohnpei Island, Ishmael Lebehn and Cindy Ehmes for assistance on Mokil Atoll, and Makir Keller and Elizabeth Keller for their aid on Pingelap Atoll. This work was supported by the Japan Society for the Promotion of Science (Project No. 22510271 and 24402006).

\section{REFERENCES}

Bohart, R. M. 1957. Insect of Micronesia Diptera: Culicidae. Bernice P. Bishop Museum. Insect of Micronesia, 1956: 1-85.

Bohart, R. M. and Ingram, R. L. 1946. Mosquitoes of Okinawa and Islands in the Central Pacific. U. S. Navmed., 1055: 1-110.

Duffy, M. R., Chen, T., Hancock, W. T., Powers, A. M., Kool, J. L., Lanciotti, R. S., Pretrick, M., Marfel, M., Holzbauer, S., Dubray, C., Guillaumot, L., Griggs, A., Bel, M., Lambert, A. J., Laven, J., Kosoy, O., Panella, A., Biggerstaff, B., Fischer, M. and Hayes, E. B. 2009. Zika virus outbreak on Yap Island, Federated States of Micronesia. N. Engl. J. Med., 360: 2536-2543.

Galbraith, K., Bendure, G. and Friary, N. 2000. Micronesia 4th edition. 368 pp., Lonely Planet Publications, Hawthorn.

Guillaumot, L. 2005. Arboviruses and their vectors in the PacificStatus report. Pac. Health Dialog., 12: 45-52.

Hayes, E. B. 2009. Zika virus outside Africa. Emerg. Infect. Dis., 15: 1347-1350.

Knight, K. L. and Hurlbut, H. S. 1949. The mosquitoes of Ponape Island, eastern Carolines. J. Wash. Acad. Sci., 39: 20-34.

Martin, B. 2005. Dengue fever type 1 outbreak in Yap. ACTION, 20: $11-12$.

Ministry of Foreign Affairs of Japan 2011. Overseas Safety HP, http://www2.anzen.mofa.go.jp/info/pcspotinfo.asp?infocode $=$ 2011C370

Ministry of Foreign Affairs of Japan 2012. Overseas Safety HP, http://www2.anzen.mofa.go.jp/info/pcspotinfo.asp?infocode $=$ 2012 C360

Noda, S., Gilmatum, J., Ogino, K., Toma, T. and Miyagi, I. 2005. Mosquitoes collected on Yap Islands and Ulithi Atoll, Yap State, Federated States of Microfnesia (Diptera: Culicidae). Med. Entomol. Zool., 56: 249-353.

Nukui, Y., Tajima, S., Kotani, A., Ito, M., Takahashi, T., Koike, K. and Kurane, I. 2006. Novel dengue virus type 1 from travelers to Yap State, Micronesia. Emerg. Infect. Dis., 12: 343-346.

Savage, H. M., Frits, C. L., Rutstein, D., Yolwa, A., Vorndam, V. and Gulbler, D. J. 1998. Epidemic of dengue-4 virus in Yap State, Federated States of Micronesia, and implication of Aedes hensilli as an epidemic vector. Am. J. Trop. Med. Hyg., 59: 519-524.

WHO 2003. Guidelines for dengue surveillance and mosquito control (Second edition). 105 pp., World Health Organization, Regional Office for the Western Pacific, Manila.

WHO2010.Number of cases of denguefeverand denguehaemorrhagic fever (DF/DFS) in the Western Pacific Region, 2000-2010. http://www.wpro.who.int/emerging_diseases/WPRO_Dengue_ Cases_2010.pdf. 